\title{
Different Roles of Top-Down and Bottom-Up Processes in the Distribution of Size-Fractionated Phytoplankton in Gwangyang Bay
}

\author{
Yoonja Kang *(i) and Yeongji Oh
}

check for updates

Citation: Kang, Y.; Oh, Y. Different Roles of Top-Down and Bottom-Up Processes in the Distribution of Size-Fractionated Phytoplankton in Gwangyang Bay. Water 2021, 13, 1682 https://doi.org/10.3390/w13121682

Academic Editor: Gang Pan

Received: 8 June 2021

Accepted: 15 June 2021

Published: 17 June 2021

Publisher's Note: MDPI stays neutral with regard to jurisdictional claims in published maps and institutional affiliations.

Copyright: (c) 2021 by the authors. Licensee MDPI, Basel, Switzerland. This article is an open access article distributed under the terms and conditions of the Creative Commons Attribution (CC BY) license (https:/ / creativecommons.org/licenses/by/ $4.0 /)$.
Department of Ocean Integrated Science, College of Fisheries and Ocean Sciences, Chonnam National University, Yeosu 59626, Korea; 194894@jnu.ac.kr

* Correspondence: yoonjakang@jnu.ac.kr; Tel.: +82-061-659-7141

\begin{abstract}
The interactive roles of zooplankton grazing (top-down) and nutrient (bottom-up) processes on phytoplankton distribution in a temperate estuary were investigated via dilution and nutrient addition experiments. The responses of size-fractionated phytoplankton and major phytoplankton groups, as determined by flow cytometry, were examined in association with zooplankton grazing and nutrient availability. The summer bloom was attributed to nanoplankton, and microplankton was largely responsible for the winter bloom, whereas the picoplankton biomass was relatively consistent throughout the sampling periods, except for the fall. The nutrient addition experiments illustrated that nanoplankton responded more quickly to phosphate than the other groups in the summer, whereas microplankton had a faster response to most nutrients in the winter. The dilution experiments ascribed that the grazing mortality rates of eukaryotes were low compared to those of the other groups, whereas autotrophic cyanobacteria were more palatable to zooplankton than cryptophytes and eukaryotes. Our experimental results indicate that efficient escape from zooplankton grazing and fast response to nutrient availability synergistically caused the microplankton to bloom in the winter, whereas the bottom-up process (i.e., the phosphate effect) largely governed the nanoplankton bloom in the summer.
\end{abstract}

Keywords: top-down effect; bottom-up effect; phytoplankton bloom; flow cytometry; estuary; Gwangyang Bay

\section{Introduction}

Phytoplankton is responsible for more than half of primary production worldwide [1] and contributes to 1-2\% of the carbon for total autotrophs across the global ocean [2]. The key role of phytoplankton in biogeochemical cycles has received much attention [2,3]. The physical and chemical variables regulating phytoplankton dynamics are well disclosed $[4,5]$, while nutrients are critical in partitioning niches among co-existing phytoplankton in the ocean [6,7]. Beyond these controlling factors, zooplankton grazing also plays an essential role in shaping phytoplankton communities [8,9]. In coastal waters, the interactive role of zooplankton grazing and nutrient supply often causes the formation of ecosystem disruptive blooms, during which harmful algae are able to avoid grazing and efficiently utilize various types of nutrient resources (e.g., the utilization of dissolved organic nitrogen when dissolved inorganic nutrients are limited) [10,11].

The interactive roles of top-down (zooplankton grazing) and bottom-up (nutrients) processes have been investigated in various ecosystems from lakes to coastal waters to the open ocean [10,12-15], and these processes have been applied to reveal the dynamics of harmful algal bloom formation [10], regime shifts in phytoplankton communities [13], and plankton dynamic models [15]. In Korean waters, however, microzooplankton grazing is considered to be an individual driver that regulates phytoplankton growth in Jinhae 
Bay [16]. The relative importance of the top-down effect on size-fractionated phytoplankton dynamics in the Juam Reservoir has been assessed using artificial neural network modeling [17]. In addition, size-selective feeding of zooplankton has been considered a driver shaping phytoplankton community structure [18]. Despite the importance of top-down and bottom-up events on phytoplankton dynamics, to the best of our knowledge, the two-sided aspects have not been simultaneously explored in Korean coastal waters.

Gwangyang Bay is a temperate estuary located in the southern coastal waters of Korea and is characterized by high productivity and low turbidity $[19,20]$. Seawater intrusion through the Yeosu Channel mixes with freshwater from the Seomjin River [21]. Anthropogenic activities such as dredging and reclamation have occurred for decades [22], altering the environmental conditions in the bay ecosystem. Although phytoplankton distribution is largely controlled by the input of nutrients via the river discharge [23] and anthropogenic inputs such as sewage treatment plants [24], zooplankton distribution is mainly governed by environmental parameters such as water temperature, dissolved oxygen (DO), and salinity in the summer [25] and the intrusion of the Tsushima Current in the fall [26]. Moreover, food availability (i.e., phytoplankton biomass) is another main controller of the zooplankton community [27]. Ecological studies in Gwangyang Bay have been broadly associated with individual factors, including phytoplankton [23,24,28], zooplankton [27,29], and fish [30,31].

Here, we investigated the interactive relationship between zooplankton grazing and nutrients in the formation of phytoplankton blooms in Gwangyang Bay. Dilution experiments were performed to assess the role of zooplankton grazing, and nutrient addition experiments were conducted to evaluate the role of nutrients in net phytoplankton growth. Furthermore, the responses of size-fractionated phytoplankton to zooplankton grazing and nutrients were investigated using size-fractionated chlorophyll a (chl a) and flow cytometry. The results were further analyzed using redundancy analysis (RDA) to summarize the responses of phytoplankton to environmental variables and principal component analysis (PCA) to determine the contribution (\%) of major nutrient compounds to the ecosystem.

\section{Materials and Methods}

\subsection{Field Survey}

Seasonal sampling was performed in May, August, and November 2020, as well as February 2021, which were representative of spring, summer, fall, and winter, respectively. Samples were collected at 11 sites throughout Gwangyang Bay and Yeosu Channel, and water for the experiments was separately collected at sites 3 and 10, which were representative of the inner bay and outer bay, respectively (Figure 1). Temperature, salinity, and DO were measured at each sampling site using a portable multi-parameter platform (YSI ProDSS; YSI Inc., Yellow Springs, OH, USA). Water samples were collected using a Niskin water sampler (General Oceanics, Miami, FL, USA) at $1 \mathrm{~m}$ below the water surface and transferred to $10 \mathrm{~L}$ acid-washed polyethylene carboys to obtain chl a, flow cytometry, and nutrient samples.

\subsection{Sample Preparation}

Upon arrival at the laboratory, triplicate $500 \mathrm{~mL}$ seawater samples were filtered onto GF/F filters ( $47 \mathrm{~mm}$; Whatman plc, Maidstone, UK) to measure the total chl a. Triplicate water samples were filtered sequentially through 20 and $2 \mu \mathrm{m}$ polycarbonate track-etched membrane filters $(47 \mathrm{~mm})$ and GF/F filters to measure size-fractionated chl a (picoplankton $<2 \mu \mathrm{m}$; nanoplankton 2-20 $\mu \mathrm{m}$; microplankton $>20 \mu \mathrm{m}$ ). For flow cytometry analysis, $4.5 \mathrm{~mL}$ of triplicate samples collected at each site was preserved with buffered formalin at a final concentration of $1 \%(0.5 \mathrm{~mL})$ and stored in a $-80^{\circ} \mathrm{C}$ freezer until analysis. Dissolved nutrient samples were collected in $20 \mathrm{~mL}$ high-density polyethylene vials by filtering onto pre-combusted GF/F filters $\left(25 \mathrm{~mm} ; 450{ }^{\circ} \mathrm{C}\right.$ for $2 \mathrm{~h}$ ), and samples were stored in a $-20^{\circ} \mathrm{C}$ freezer until analysis. 


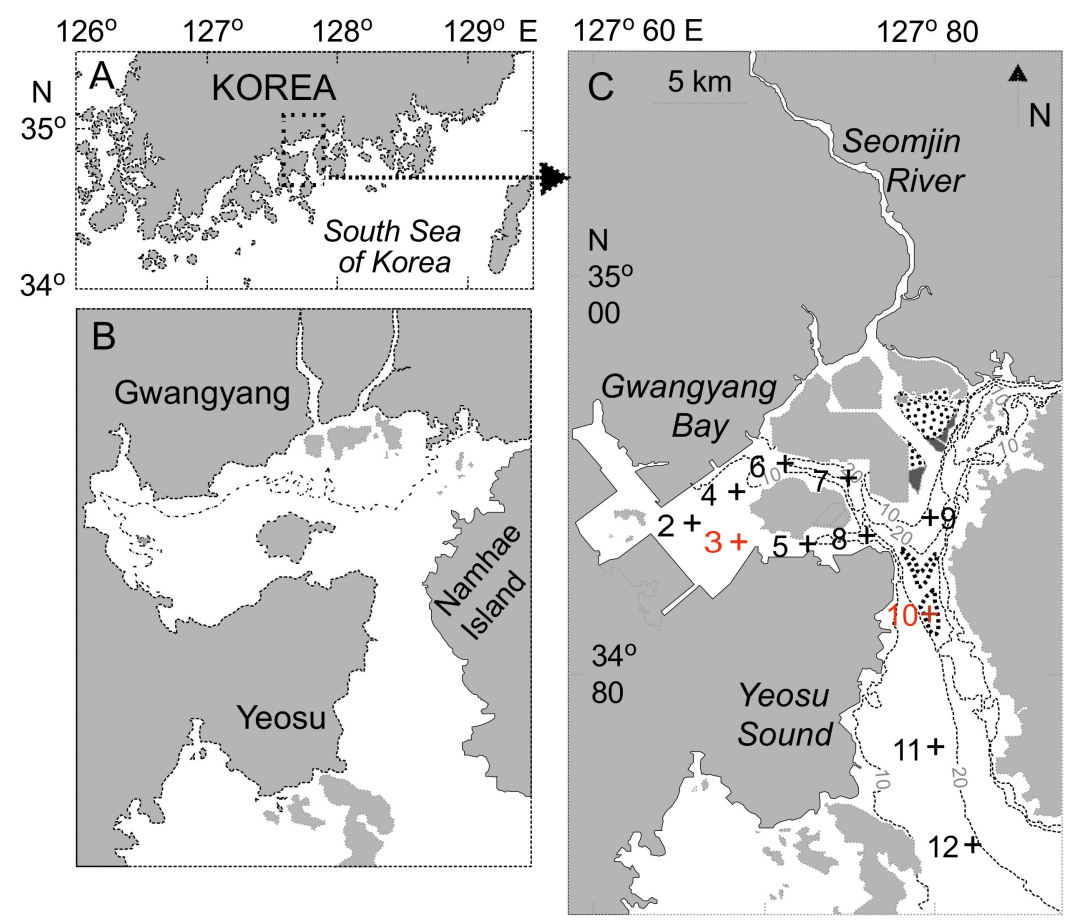

Figure 1. A map showing the sampling sites, including experimental sites 3 and 10, which are highlighted in red. (A) the locationof Gwangyang Bay, (B) the appearance of the bay before the reclamation of tidal flats in 1982, and (C) the sampling stations in the bay. Sites 2-8 were defined as the inner bay, while sites 9-12 were representative of the outer bay.

\subsection{Dilution Experiments for Determining Top-Down Effects}

Dilution experiments were performed in the summer and winter to assess the role of zooplankton using the whole seawater and seawater filtered onto $0.2 \mu \mathrm{m}$ polycarbonate filters that was collected at sites 3 and 10. The unfiltered seawater was mixed with the filtered seawater at dilution levels of $100 \%, 70 \%, 40 \%$, and $15 \%$. To ensure a nutrient-replete condition, $10 \mu \mathrm{M}$ of nitrate and $1 \mu \mathrm{M}$ of phosphate were amended to triplicate $1 \mathrm{~L}$ Nalgene PET bottles [9]. Bottles were incubated at the ambient temperatures at which they were obtained during the seasonal field survey with a 12:12 h light:dark cycle [32] illuminated by a bank of fluorescent lights $\left(100 \mu \mathrm{mol}\right.$ photons $\left.\mathrm{m}^{-2} \mathrm{~s}^{-1}\right)$. After $24 \mathrm{~h}$ of incubation, three $4.5 \mathrm{~mL}$ samples were preserved with buffered formalin at a final concentration of $1 \%$ $(0.5 \mathrm{~mL})$ and stored in $\mathrm{a}-80{ }^{\circ} \mathrm{C}$ freezer until analysis.

\subsection{Nutrient Addition Experiments for Determining Bottom-Up Effects}

Nutrient addition experiments were performed in the summer and winter to investigate the response of size-fractionated phytoplankton to different nutrient compounds. Triplicate $1 \mathrm{~L}$ Nalgene PET bottles were filled with the whole seawater and enriched with nitrate $(10 \mu \mathrm{M})$, phosphate $(1 \mu \mathrm{M})$, silicate $(10 \mu \mathrm{M})$, and a combination of nitrate and phosphate, while a set of triplicate bottles was left intact as a control treatment. The levels of added nutrients matched those historically observed in this ecosystem [23]. Experiment bottles were incubated as described above. After $24 \mathrm{~h}$ of incubation, $300 \mathrm{~mL}$ of samples was sequentially filtered onto different size filters to measure size-fractionated $\mathrm{chl}$ a as described above. Net growth rates of individual phytoplankton populations were calculated using the formula $k=\ln \left(\mathrm{B}_{\mathrm{t}} / \mathrm{B}_{0}\right) / t$, where $k$ is the net growth rate, $\mathrm{B}_{\mathrm{t}}$ is the chl a of each size group at the initiation of the experiments, $B_{0}$ is the chl a of each size group at the end of the experiments, and $t$ is the experimental duration in days. Differences in the net growth rates of each phytoplankton group between the control and each treatment were examined to evaluate how different sizes of phytoplankton groups respond to various nutrient compounds. 


\subsection{Sample Analysis}

The cell abundance of eukaryotes, cyanobacteria, including phycocyanin-containing cyanobacteria (PC cyanobacteria, hereafter) and phycoerythrin-containing cyanobacteria (PE cyanobacteria, hereafter), and cryptophytes was determined using a flow cytometer (Becton, Dickinson and Company, Franklin Lakes, NJ, USA) at the National Institute of Fisheries Science (NIFS) in Yeosu, South Korea. Fluorescent beads (diameter of $2 \mu \mathrm{M}$ ) were utilized to determine the picoplankton, and each sample was run on the flow cytometer for $3 \mathrm{~min}$ at a mid-rate to obtain sufficient particle numbers for precise and accurate cell densities. The sampling running time and speed remained consistent during the flow cytometry analysis $[10,33]$. PC and PE cyanobacteria were verified by the relative contents of chl a and phycoerythrin pigment in cells. The fact that PC cyanobacteria have a low $\mathrm{PE}: \mathrm{Chl}$ a ratio and $\mathrm{PE}$ cyanobacteria have a high PE:Chl a ratio was applied to determine the PC and PE cyanobacteria populations. Eukaryotic algae exhibited significantly higher levels of chl a, and cryptophytes showed significantly higher levels of phycoerythrin compared to those in the other groups. The abundance of major phytoplankton groups was finally determined using a BD Accuri C6 Plus software. The final cell density was presented in cells $/ \mathrm{mL}$.

Nutrients, including dissolved inorganic nitrogen (DIN; the summation of nitrate, nitrite, and ammonium), dissolved inorganic phosphate (DIP), and silicate, were analyzed in duplicate using a SEAL QuAAtro Auto Analyzer (Seal Analytical Ltd., Southampton, UK) at NIFS. Size-fractionated chl a was measured using a TrilogyTM fluorometer (Turner Designs, Sunnyvale, CA, USA) after extracting chl a with $90 \%$ acetone for $24 \mathrm{~h}$ at $-20^{\circ} \mathrm{C}$.

\subsection{Data Analysis}

$\mathrm{N}: \mathrm{P}, \mathrm{Si}: \mathrm{P}$, and N:Si ratios were calculated using dissolved inorganic nutrients throughout the sampling periods and compared between the inner and outer bays. The N:P ratio is representative of the DIN:DIP ratio, the Si:P ratio is the silicate:DIP ratio, and the N:Si ratio is the DIN: silicate ratio. The true nutrient limitations, particularly P- and Si-limitation, were obtained based on a combination of those ratios, including N:P vs. Si:P and SiLN vs. Si:P. PCA was executed to evaluate the contribution (\%) of major dissolved nutrient compounds, and RDA was performed to illustrate the most important environmental variables in the phytoplankton distribution in this ecosystem. Statistical analyses were executed in R version 3.6.2 (R Foundation for Statistical Computing, Vienna, Austria) using the 'vegan' and 'FactorMineR' packages for RDA and PCA, respectively. Plots were created using the package 'ggplot2'.

\section{Results}

\subsection{Environmental Variations}

Seasonal variations in environmental parameters are illustrated in Figure 2. The mean temperature peaked at $25.5^{\circ} \mathrm{C}$ in the summer, while it gradually declined to $10.0^{\circ} \mathrm{C}$ in the winter (Figure 2A). The lowest salinity was detected in the summer $(19.3 \%)$, whereas salinity remained stable in the other seasons (Figure 2B). DO was fairly consistent, ranging from $7.7 \mathrm{mg} / \mathrm{L}$ in the fall to $9.2 \mathrm{mg} / \mathrm{L}$ in the winter (Figure 2C). DIN levels were significantly high in the summer at $68.8 \mu \mathrm{M}$ and sharply declined in the other seasons, with the lowest value detected in the winter $(1.0 \mu \mathrm{M}$; Figure 2D). DIP and silicate had a similar pattern to that of the DIN variation throughout the year, with the highest values in the summer at $1.7 \mu \mathrm{M}$ of DIP and $99.5 \mu \mathrm{M}$ of silicate (Figure $2 \mathrm{E}, \mathrm{F}$ ). 

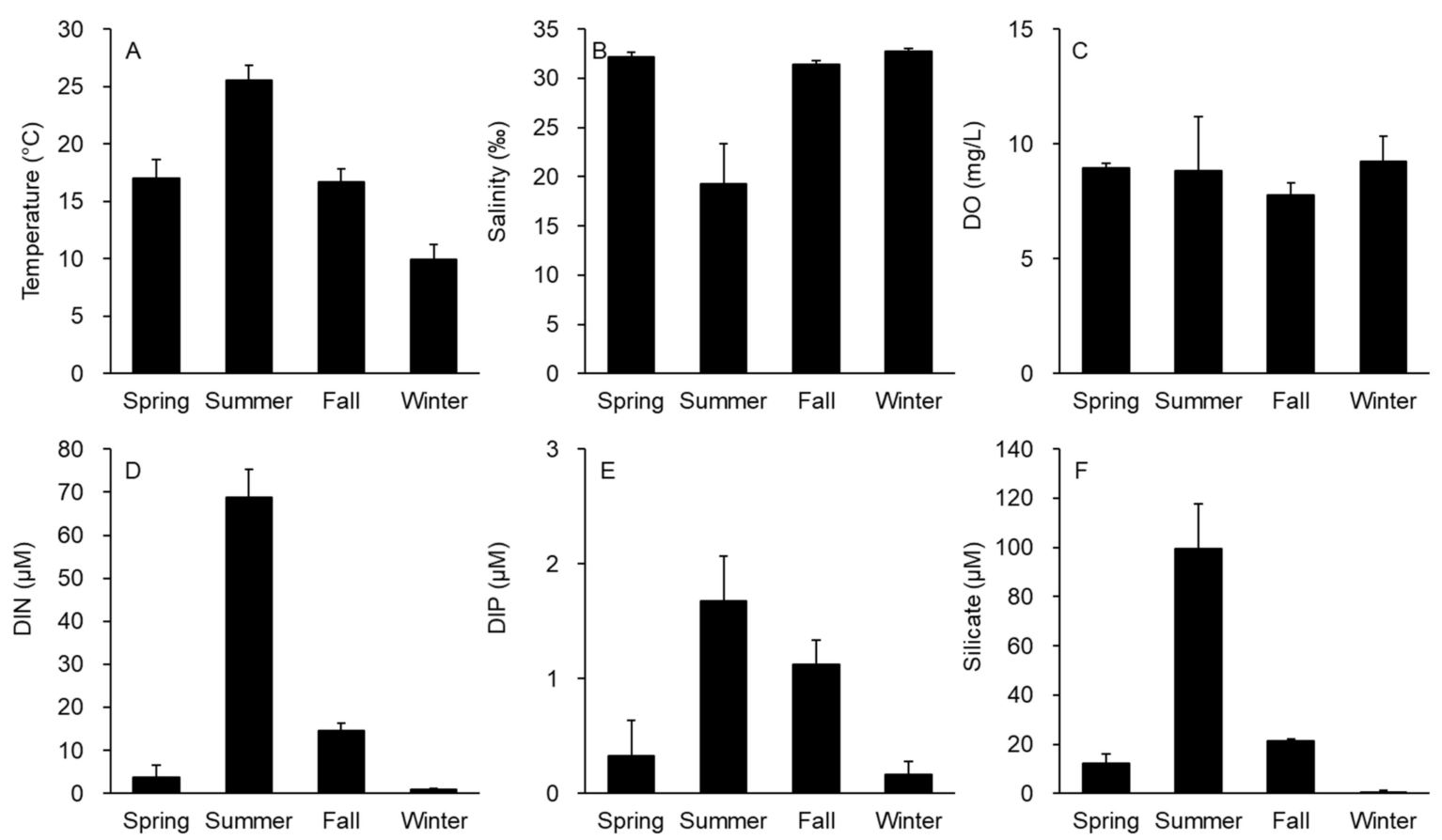

Figure 2. Seasonal variations in environmental variables, including (A) temperature $\left({ }^{\circ} \mathrm{C}\right),(\mathbf{B})$ salinity $(\%$ ), (C) dissolved oxygen (DO; mg/L), (D) dissolved inorganic nitrogen (DIN; $\mu \mathrm{M}),(\mathbf{E})$ dissolved inorganic phosphate (DIP; $\mu \mathrm{M})$, and (F) silicate $(\mu \mathrm{M})$.

The contribution (\%) of major nitrogen compounds to the Gwangyang Bay ecosystem was determined via PCA. Nitrate $(83.7 \%)$, ammonium $(70.4 \%)$, and phosphate $(60.1 \%)$ contributed more than $50 \%$, while nitrite and silicate were responsible for less than $50 \%$ of the contribution (Figure 3).

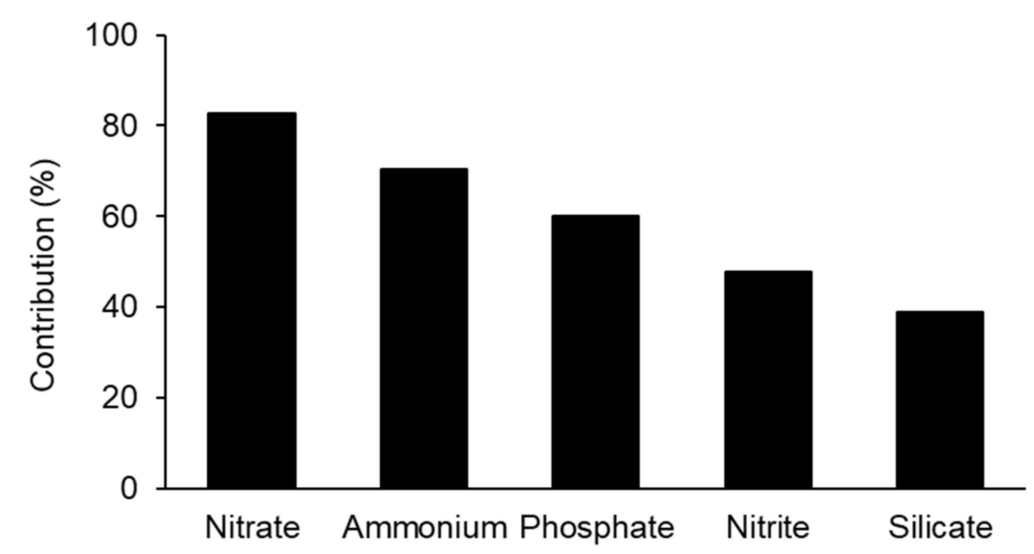

Figure 3. The contribution of the five major nutrient compounds to the Gwangyang Bay ecosystem as determined by principal component analysis.

The combination of Redfield ratios presented the true nutrient limitations. The combination of the Si:N and N:P ratios exhibited the true N-limitations in the inner and outer bays during the study period. In the winter, $\mathrm{N}$ was limited, but the extent of $\mathrm{N}$-limitation was significantly severe in the spring (Figure 4A). P-limitation gradually increased in the spring, and the limitation peaked in the summer (Figure 4B). Silicate was entirely limited in the winter, whereas the limitation was weakened in the summer and spring (Figure $4 \mathrm{C}$ ). There was no significant difference in the nutrient limitations between the inner and outer bays. 

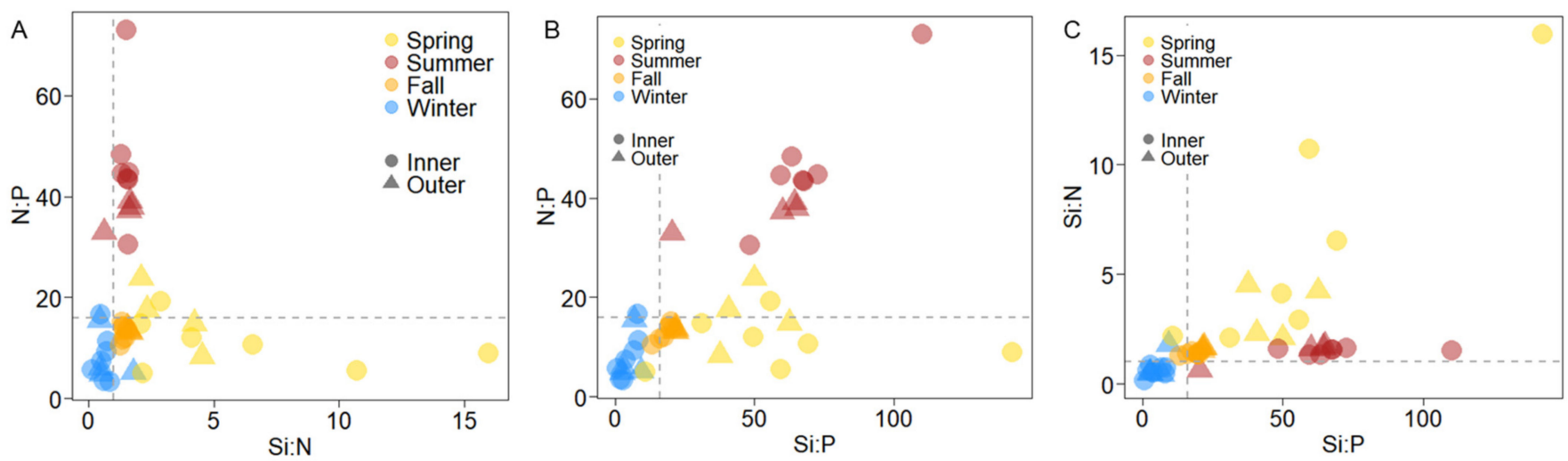

Figure 4. Redfield ratios showing the true nutrient limitations. (A) N-limitation via a combination of the Si:N and N:P ratios, (B) P-limitation via a combination of the Si:P and N:P ratios, and (C) Si-limitation via a combination of the Si:P and Si:N ratios.

\subsection{Phytoplankton Biomass Variations}

Total phytoplankton biomass varied from $1.0 \mu \mathrm{g} / \mathrm{L}$ in the fall to $11.8 \mu \mathrm{g} / \mathrm{L}$ in the winter (Figure 5A), whereas each size-fractionated phytoplankton biomass peaked in different seasons (Figure 5). The chl a of microplankton ranged from $0.2 \mu \mathrm{g} / \mathrm{L}$ in the fall to $8.3 \mu \mathrm{g} / \mathrm{L}$ in the winter (Figure 5B), whereas the highest chl a concentration of nanoplankton and picoplankton was displayed in the summer $(5.3 \mu \mathrm{g} / \mathrm{L})$ and spring $(1.8 \mu \mathrm{g} / \mathrm{L})$, respectively (Figure 5C,D). However, the picoplankton biomass was relatively consistent throughout the sampling periods, except for the fall (Figure 5D).
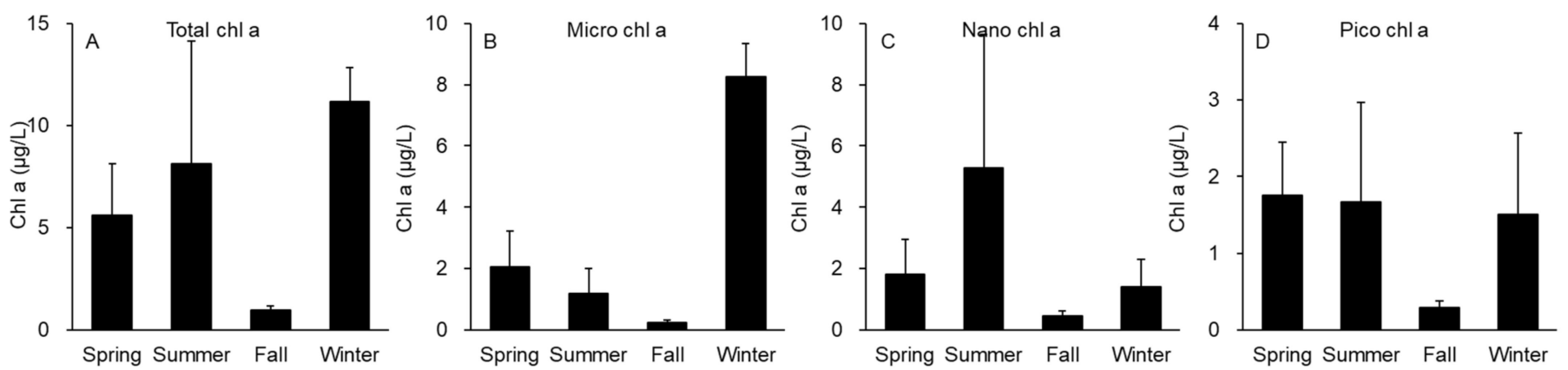

Figure 5. Phytoplankton biomass (chlorophyll a) in Gwangyang Bay: (A) total chlorophyll a (chl a), (B) microplankton chl a, (C) nanoplankton chl a, and (D) picoplankton chl a.

The phytoplankton community was largely categorized into three groups: winter, a mixture of summer and fall, and a mixture of spring and fall (Figure 6). The mixture of summer and fall groups was positively correlated with temperature and nutrients, while the other two groups were negatively correlated with those parameters but positively correlated with DO and salinity (Figure 6). 


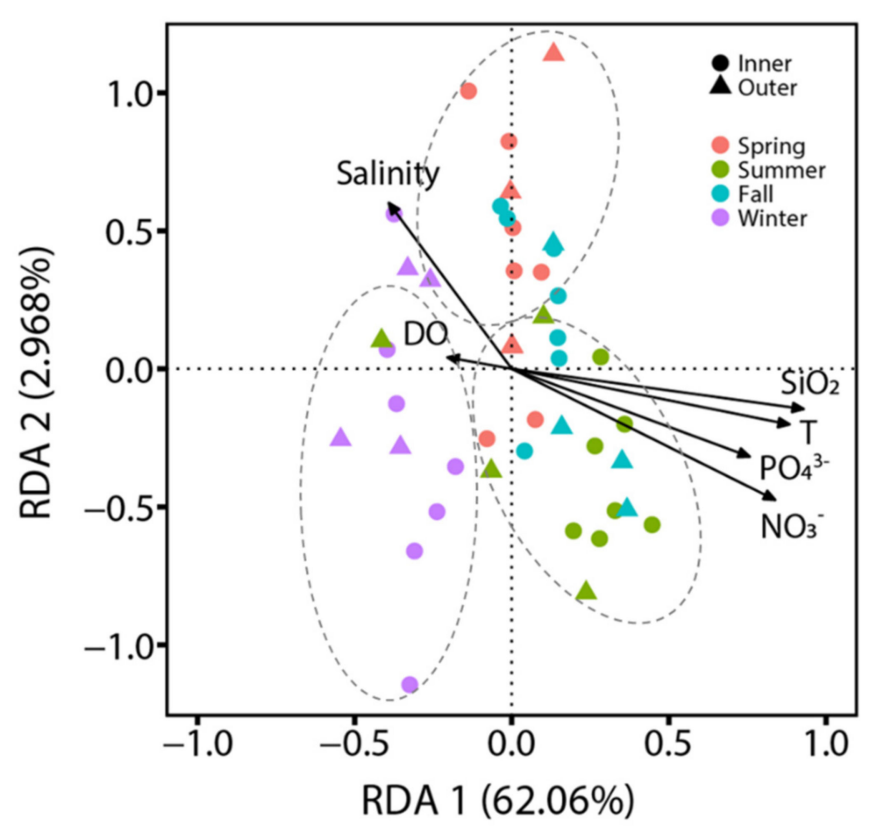

Figure 6. Redundancy analysis (RDA) presenting the relationship between the phytoplankton community and environmental variables during the sampling periods in the inner and outer bays of Gwangyang Bay. Abbreviations are as follows: $\mathrm{DO}=$ dissolved oxygen, $\mathrm{T}=$ temperature.

\subsection{Effects of Nutrients and Zooplankton Grazing}

The response of size-fractionated phytoplankton to nutrient compounds differed among the groups. In the inner bay during the summer survey, the responses of picoplankton to nitrate and silicate additions were significantly faster than those of nanoplankton and microplankton, while nanoplankton responded faster to phosphate addition than the other phytoplankton groups (Figure 7A). The responses of size-fractionated phytoplankton to nutrient additions in the outer bay were similar to those in the inner bay (Figure 7B); however, the growth differences of picoplankton in the inner bay were two-fold higher in response to nitrate addition and nine-fold higher in response to silicate addition compared to those in the outer bay (Figure 7A,B). Interestingly, the growth difference in nanoplankton in response to phosphate addition was fairly consistent between the two water systems $\left(0.30 \mathrm{~d}^{-1}\right.$ in the inner bay and $0.28 \mathrm{~d}^{-1}$ in the outer bay; Figure $\left.7 \mathrm{~A}, \mathrm{~B}\right)$. In the summer, small phytoplankton (picoplankton and nanoplankton) exhibited a smaller response to nutrient addition compared to that of large phytoplankton (microplankton); the growth rate of microplankton sharply increased with the nutrient additions (Figure 7C,D). Particularly, the response of microplankton to silicate addition was the second-highest in the inner bay but the lowest in the outer bay (Figure 7C,D), although the general responses of the size-fractionated groups were significantly lower in the outer bay (Figure 7D). In addition, the combination of nitrate and phosphate synergistically increased the growth rate in microplankton in both the inner and outer bays (Figure 7C,D). 

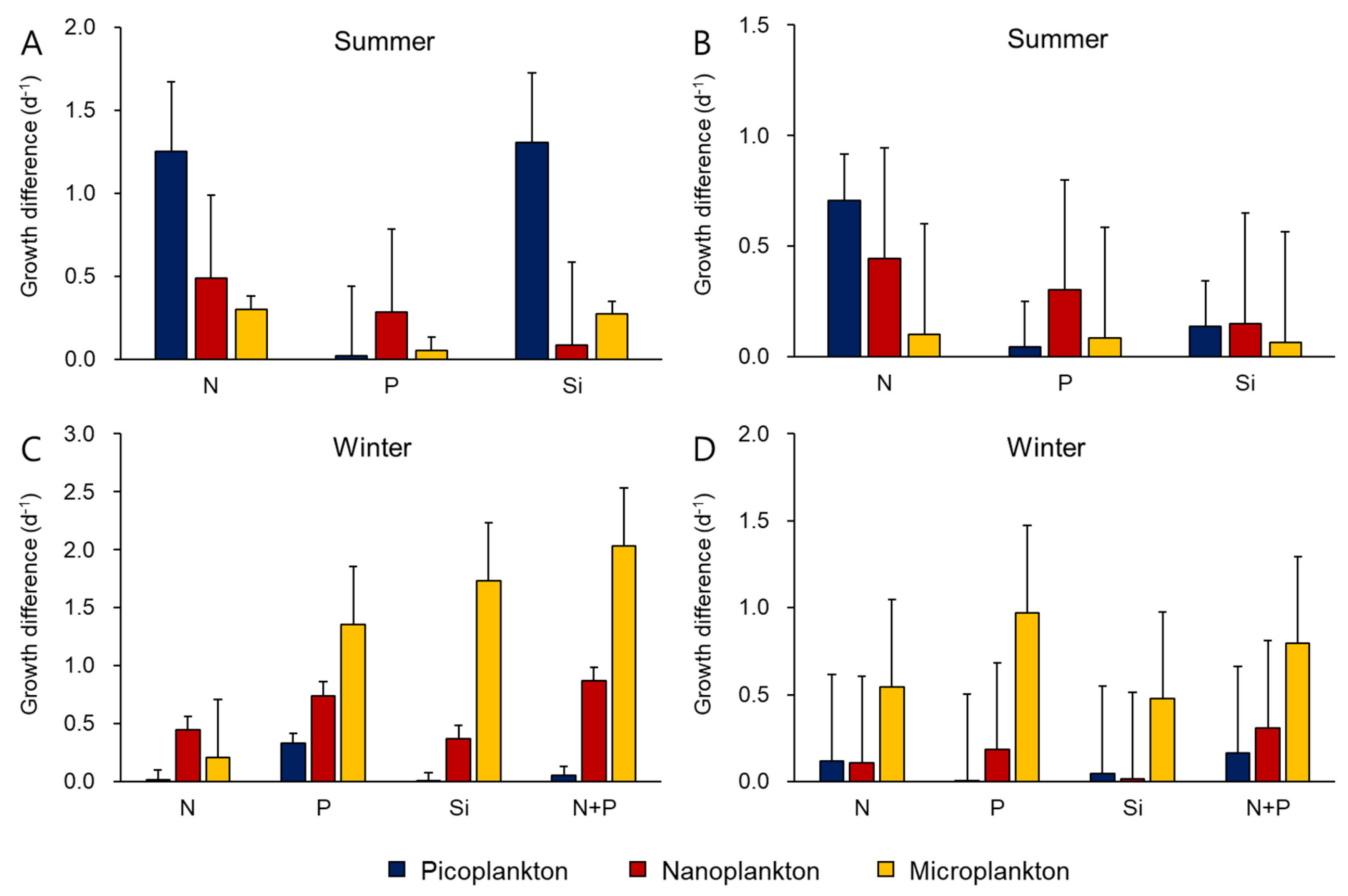

Figure 7. Growth differences $\left(\mathrm{d}^{-1}\right)$ of size-fractionated phytoplankton in response to nitrate, phosphate, silicate, and a combination of nitrate and phosphate. (A) Growth differences in the inner bay in the summer, (B) growth differences in the outer bay in the summer, $(\mathbf{C})$ growth differences in the inner bay in the winter, and (D) growth differences in the outer bay in the winter. Abbreviations are as follows: $\mathrm{N}=$ nitrate, $\mathrm{P}=$ phosphate, $\mathrm{Si}=$ silicate, and $\mathrm{N}+\mathrm{P}=$ the combination of nitrate and phosphate.

The dilution experiments elucidated the grazing mortality rates $\left(\mathrm{d}^{-1}\right)$ of the major phytoplankton groups, including eukaryotes, PC cyanobacteria, PE cyanobacteria, and cryptophytes. In the inner bay, cryptophytes had the highest grazing mortality rates $\left(1.3 \mathrm{~d}^{-1}\right)$, whereas, in the outer bay, both types of cyanobacteria had the highest grazing mortality rates $\left(0.9 \mathrm{~d}^{-1}\right.$ for PC cyanobacteria and $1.7 \mathrm{~d}^{-1}$ for PE cyanobacteria; Figure 8). Furthermore, the grazing mortality rates of eukaryotes were relatively low $\left(0.6 \mathrm{~d}^{-1}\right.$ in the inner bay and $0.2 \mathrm{~d}^{-1}$ in the outer bay) compared to those of the other groups (Figure 8).
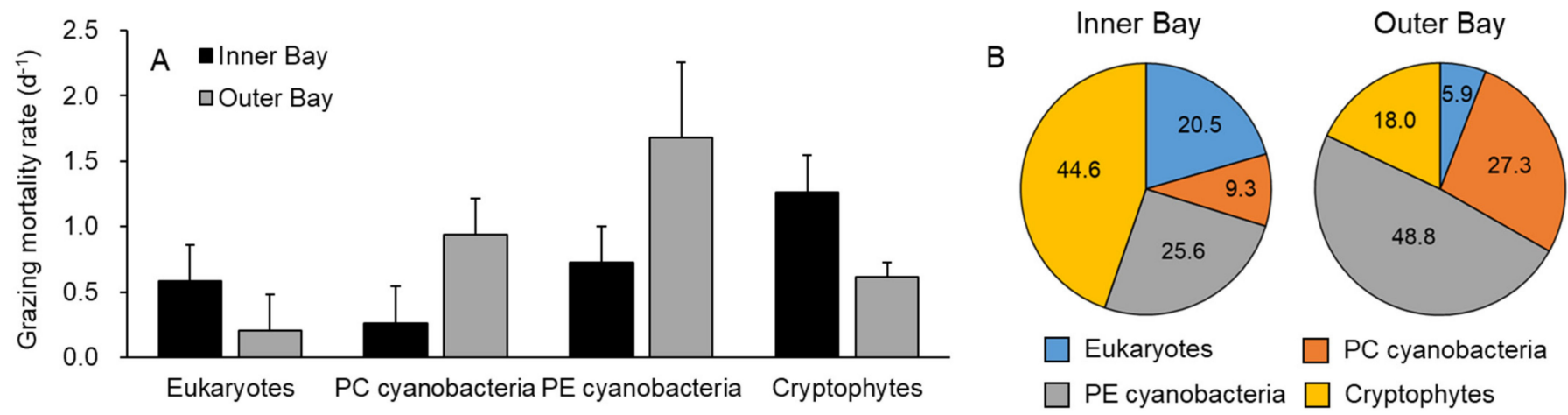

Figure 8. Grazing mortality rates $\left(\mathrm{d}^{-1}\right)$ and relative grazing rates (\%) of the major phytoplankton groups as estimated using flow cytometry. (A) Grazing mortality rates of the major phytoplankton groups and (B) relative grazing rates of the major phytoplankton groups in the inner and outer bays. Abbreviations are as follows: PC cyanobacteria = phycocyanin-containing cyanobacteria, PE cyanobacteria = phycoerythrin-containing cyanobacteria. 


\section{Discussion}

\subsection{Environmental Variables in Relation to Size-Fractionated Phytoplankton Dynamics}

Multiple nutrient compounds such as nitrate, ammonium, and phosphate affected the Gwangyang Bay ecosystem as a whole. The individual contribution of those nutrients revealed through PCA exceeded 50\%, indicating that they were the main nutrient drivers that shape the phytoplankton community. In addition, the Redfield ratios demonstrated that the true nutrient limitation differed seasonally, as $\mathrm{N}$-limitation prevailed in the spring while P-limitation and Si-limitation were dominant in the summer and winter, respectively. This implies that the dominant phytoplankton in each season was interactively associated with the major contributing nutrients because phytoplankton actively consumes nutrients for growth, and the amount of nutrients can also determine to what extent phytoplankton biomass or growth can be obtained. Particularly, nitrogen was limited in the spring when the mixed phytoplankton bloom occurred, indicating that the reliance of most phytoplankton on a nitrogen source was relatively heavy. When P-limitation was severe in the summer, nanoplankton predominated, as nanoplankton bloom formation was related to phosphate variations in this ecosystem. In the winter, when no N- or P-limitations were present but Si-limitation was, the microplankton growth was controlled by silicate, and vice versa.

Chroomonas sp. and Eucampia zodiacus were the bloom causative species in the summer and winter, respectively (Unpublished data). Although cryptophytes mainly reside in freshwater ecosystems [34], they conventionally cause blooms in Gwangyang Bay [28,35,36]. Klaveness [37] determined that as opportunists, cryptophytes can proliferate at a fast rate when the growth of competing algae is not favored. An increase in phosphate levels leads to cryptophyte blooms in the Krka River estuary in the eastern Adriatic Sea [38]; however, how their dynamics are associated with nutrient limitations is not well known. In Gwangyang Bay, cryptophyte growth appears to be favored in the fall when weakened stratification propagates water column mixing [35] or tides transport cryptophytes from the Seomjin River estuary to the Yeosu Channel [28]. In the study region, P-deficiency (i.e., DIP $<0.2 \mu \mathrm{M}$; Dortch and Whitledge [39]) was not detected, but P-limitation was enhanced in the summer during the nanoplankton bloom. In addition, the DIP levels were highest in the summer among the four seasons. Consistent with our results, Lee, Park, and Baek [28] reported that cryptophytes are one of the major phytoplankton groups and are able to resist high P-limitation in the Seomjin River estuary. Cryptophyte blooms in Yeongil Bay, located in the southern East Sea of Korea, are also triggered by P-limitation (unpublished data). This accumulating evidence suggests that the DIP levels were sufficient to support cryptophyte growth but low enough to suppress the growth of other phytoplankton, and P-limitation potentially enabled cryptophytes to form the summer bloom, taking over an ecological niche in Gwangyang Bay. In contrast to the summer bloom, the winter bloom was characterized by increased Si-limitation and a fairly low silicate level $(0.7 \mu \mathrm{M})$, which is lower than the level that inhibits phytoplankton growth (i.e., silicate $<2 \mu \mathrm{M}$; Dortch and Whitledge [39]). Given that the chl a concentrations were high and the winter bloom was composed of diatoms, specifically Eucampia zodiacus, substantial consumption by the bloom causative organism and low river discharge compared to other seasons potentially facilitated the winter bloom. Moreover, $\mathrm{N}$ and $\mathrm{P}$ were not limited in the winter, further suggesting that nutrient levels were ample to propel the formation of the diatom bloom.

The zooplankton community was not examined in this study; however, a literature review was performed to identify the dominant zooplankton groups in Gwangyang Bay during the summer and winter. The dominant copepod species in Gwangyang Bay are Paracalanus parvus s. 1 . in the summer and Acartia omorii in the winter [27,40]. Paracalanus parous s. 1., which is a small copepod that has sensory capabilities to capture food, mainly occurs in temperate coastal waters in the summer [41] and selectively feeds on small particles [42]. Thus, it is hypothesized that during the study period, Paracalanus parous s. 1. was the main grazer on cryptophytes whose size is about $10 \mu \mathrm{m}$. Moreover, the fact that warming enhances microzooplankton grazing in eutrophic waters [43] further underpins 
the enhanced grazing of microzooplankton on nanoplankton and cryptophytes in the summer; therefore, the role of microzooplankton on the small phytoplankton distribution was not negligible. In the winter, Acartia omorii often comprises more than $40 \%$ of the zooplankton abundance [40]. During a diatom bloom, there may be a food limitation in Acartia omorii, as the physiology of this species, such as egg production, readily changes with food availability [44]. Although the food quality of diatoms is questionable due to diatom toxicity [45], copepod abundance in Gwangyang Bay is positively correlated with diatom abundance $[27,40]$.

\subsection{Interactive Roles of Top-Down and Bottom-Up Effects}

Although the temperature is often a foremost controller in phytoplankton growth [46], the response rate to available nutrients determines the growth rates of most phytoplankton in oceanic ecosystems [47-50]. Growth differences between the control and treatment groups in the summer and winter distinctively showed the role of major nutrients in the formation of nanoplankton and microplankton blooms, respectively. Although picoplankton responded quickly to nitrate and silicate compared to the response of the other groups in the summer, nanoplankton outcompeted the other groups for phosphate and were also responsible for the summer bloom, which was related to P-limitation but not P-deficiency. This indicates that P-limitation suppressed the growth of competing algae, specifically microplankton, but stimulated nanoplankton growth. In the winter, microplankton dominated the utilization of nutrients added during the experiments. The combination of nitrate and phosphate synergistically enhanced microplankton growth, while the phosphate and silicate additions also boosted their growth, indicating that nutrients were limited in the microplankton populations. Interestingly, the growth differences in nanoplankton were not significantly different between the inner and outer bays in the summer, but those in picoplankton and microplankton were more than two-fold higher in the inner bay than those in the outer bay. However, in the winter, the growth differences in nanoplankton and microplankton were more than two-fold higher in the inner bay than those in the outer bay, while the growth differences in picoplankton were relatively stable. This potentially indicates that in the winter, nutrients were more limited for microplankton in forming a bloom in the inner bay than in the outer bay, whereas in the summer, nanoplankton experienced a similar extent of nutrient limitations throughout the study region.

In general, the grazing mortality rates were high on small phytoplankton compared to those on eukaryotes. This indicates that the winter bloom-occurring organism (i.e., Eucampia zodiacus) was not palatable for zooplankton, thereby allowing the massive bloom formation, whereas the summer bloom led by cryptophytes was more attributed to the nutrient status (i.e., the phosphate effect). Furthermore, the autotrophic cyanobacteria bloom was restricted by high grazing processes. The grazing rates on eukaryotes and cryptophytes were doubled in the inner bay, whereas the grazing on autotrophic cyanobacteria was higher in the outer bay than that in the inner bay. In particular, the grazing on PE cyanobacteria almost doubled from the inner bay to the outer bay, but the grazing on PC cyanobacteria increased three-fold, indicative of group-specific grazing by zooplankton in Gwangyang Bay. The feeding behaviors of the zooplankton in the study region have not gained much attention; however, selective grazing of zooplankton on edible algae often drives the formation of harmful algal blooms in coastal ecosystems [51]. The ability of Acartia to feed on picocyanobacteria if abundant is well described via qPCR targeting ITS-1 rDNA sequence of Synechococcus spp. in other regions [52], while the selectivity mode, either being passive or active, consequentially impacts the nutrient turnover rates [53]. Moreover, relatively high grazing rates on autotrophic cyanobacteria and cryptophytes indicate that small phytoplankton play a leading role in transferring carbon to the upper trophic levels through food webs in the study region. Altogether, these results highlight that the phytoplankton community was closely linked to environmental variables, and the synergistic effects of zooplankton grazing and nutrients or biased effects of either 
process interchangeably controlled the phytoplankton dynamics depending on the major dominance of blooms.

\section{Conclusions}

We examined the interactive role of top-down and bottom-up processes in phytoplankton dynamics in Gwanyang Bay via dilution and nutrient amendment experiments. Heavy zooplankton grazing controlled picoplankton while nanoplankton efficiently accessed to a limited nutrient (i.e., phosphate) experiencing relatively moderate zooplankton grazing. In contrast to picoplankton and nanoplankton, both fast responses to most nutrients and efficient escape from zooplankton grazing facilitated the microplankton bloom in the winter. Although the grazing on autotrophic cyanobacteria remained relatively high compared to that on other groups, the grazing on autotrophic cyanobacteria was group-specific and region-specific as the grazing on PE cyanobacteria was almost doubled than that on PC cyanobacteria, and the grazing on PC and PE cyanobacteria was higher in the outer bay than in the inner bay. Our results highlighted the group-specific reaction to nutrients and zooplankton grazing drives the group-specific bloom throughout the year. Given that Gwangyang Bay is characterized by distinct water masses influenced by the Seomjin River discharge and the seawater intrusion from the South Sea of Korea, a close investigation on water-mass-specific responses of major phytoplankton groups is necessary in the future.

Author Contributions: Funding acquisition, supervision, and writing, Y.K.; field survey and data analysis, Y.O. Both authors have read and agreed to the published version of the manuscript.

Funding: This study was financially supported by the "Long-Term Marine Ecosystem Research (III): Environmental change and ecosystem response of Korean waters affected by Tsushima Current" grant funded by the Ministry of Oceans and Fisheries, Korea, and the Basic Science Research Program through the National Research Foundation of Korea funded by the Ministry of Education (2020R1F1A1076628).

Institutional Review Board Statement: Not applicable.

Informed Consent Statement: Not applicable.

Data Availability Statement: Not applicable.

Acknowledgments: We appreciate the students who assisted with the field survey.

Conflicts of Interest: The authors declare that they have no known competing financial interests or personal relationships that could have appeared to influence the work reported in this paper.

\section{References}

1. Field, C.B.; Behrenfeld, M.J.; Randerson, J.T.; Falkowski, P. Primary production of the biosphere: Integrating terrestrial and oceanic components. Science 1998, 281, 237-240. [CrossRef] [PubMed]

2. Falkowski, P.G. The role of phytoplankton photosynthesis in global biogeochemical cycles. Photosynth. Res. 1994, 39, $235-258$. [CrossRef] [PubMed]

3. Falkowski, P.G.; Barber, R.T.; Smetacek, V. Biogeochemical controls and feedbacks on ocean primary production. Science 1998, 281, 200-206. [CrossRef] [PubMed]

4. Sunagawa, S.; Coelho, L.P.; Chaffron, S.; Kultima, J.R.; Labadie, K.; Salazar, G.; Djahanschiri, B.; Zeller, G.; Mende, D.R.; Alberti, A.; et al. Structure and function of the global ocean microbiome. Science 2015, 348, 1261359. [CrossRef] [PubMed]

5. Marinov, I.; Doney, S.C.; Lima, I.D. Response of ocean phytoplankton community structure to climate change over the 21st century: Partitioning the effects of nutrients, temperature and light. Biogeosciences 2010, 7, 3941-3959. [CrossRef]

6. Alexander, H.; Jenkins, B.D.; Rynearson, T.A.; Dyhrman, S.T. Metatranscriptome analyses indicate resource partitioning between diatoms in the field. Proc. Natl. Acad. Sci. USA 2015, 112, E2182-E2190. [CrossRef] [PubMed]

7. Gomes, H.D.R.; Xu, Q.; Ishizaka, J.; Carpenter, E.J.; Yager, P.L.; Goes, J.I. The influence of riverine nutrients in niche partitioning of phytoplankton communities-A contrast between the Amazon River Plume and the Changjiang (Yangtze) River diluted water of the East China Sea. Front. Mar. Sci. 2018, 5, 343. [CrossRef]

8. Behrenfeld, M.J. Abandoning Sverdrup's Critical Depth Hypothesis on phytoplankton blooms. Ecology 2010, 91, 977-989. [CrossRef] [PubMed]

9. Landry, M.R.; Kirshtein, J.; Constantinou, J. A refined dilution technique for measuring the community grazing impact of microzooplankton, with experimental tests in the central equatorial Pacific. Mar. Ecol. Prog. Ser. 1995, 120, 53-63. [CrossRef] 
10. Kang, Y.; Koch, F.; Gobler, C.J. The interactive roles of nutrient loading and zooplankton grazing in facilitating the expansion of harmful algal blooms caused by the pelagophyte, Aureoumbra lagunensis, to the Indian River Lagoon, FL, USA. Harmful Algae 2015, 49, 162-173. [CrossRef]

11. Gobler, C.J.; Renaghan, M.J.; Buck, N.J. Impacts of nutrients and grazing mortality on the abundance of Aureococcus anophagefferens during a New York brown tide bloom. Limnol. Oceanogr. 2002, 47, 129-141. [CrossRef]

12. Anneville, O.; Chang, C.W.; Dur, G.; Souissi, S.; Rimet, F.; Hsieh, C.H. The paradox of re-oligotrophication: The role of bottom-up versus top-down controls on the phytoplankton community. Oikos 2019, 128, 1666-1677. [CrossRef]

13. Ibáñez, C.; Alcaraz, C.; Caiola, N.; Rovira, A.; Trobajo, R.; Alonso, M.; Duran, C.; Jiménez, P.J.; Munné, A.; Prat, N. Regime shift from phytoplankton to macrophyte dominance in a large river: Top-down versus bottom-up effects. Sci. Total Environ. 2012, 416, 314-322. [CrossRef]

14. Thompson, P.A.; Bonham, P.I.; Swadling, K.M. Phytoplankton blooms in the Huon Estuary, Tasmania: Top-down or bottom-up control? J. Plankton Res. 2008, 30, 735-753. [CrossRef]

15. Stock, C.A.; Powell, T.M.; Levin, S.A. Bottom-up and top-down forcing in a simple size-structured plankton dynamics model. J. Mar. Syst. 2008, 74, 134-152. [CrossRef]

16. Kim, S.; Park, M.G.; Moon, C.; Shin, K.; Chang, M. Seasonal variations in phytoplankton growth and microzooplankton grazing in a temperate coastal embayment, Korea. Estuar. Coast. Shelf Sci. 2007, 71, 159-169. [CrossRef]

17. Sin, Y.-S.; Song, E.-S.; Lim, J.-S.; Chang, N.-I. Relative importance of bottom-up vs. top-down controls on size-structured phytoplankton dynamics in a freshwater ecosystem: II. Investigation of controlling factors using statistical modeling analysis. Korean J. Ecol. Environ. 2005, 38, 445-453.

18. Jang, M.-C.; Shin, K.; Lee, T.; Noh, I. Feeding selectivity of calanoid copepods on phytoplankton in Jangmok Bay, south coast of Korea. Ocean Sci. J. 2010, 45, 101-111. [CrossRef]

19. Kim, J.-K.; Kim, M.-W.; Lee, M.-O.; Kang, T.-S. The Characteristics of Estuarine Tidal Circulation in Gwangyang Bay. Proc. Korean Soc. Mar. Environ. Energy 2005, 5, 139-143.

20. Kwon, K.-Y.; Moon, C.-H.; Kang, C.-K.; Kim, Y.-N. Distribution of particulate organic matter along the salinity gradients in the Seomjin River estuary. J. Korean Fish. Aquat. Sci. 2002, 35, 86-96.

21. Jang, P.-G.; Lee, W.-J.; Jang, M.-C.; Lee, J.-D.; Lee, W.-J.; Chang, M.; Hwang, K.-C.; Shin, K.-S. Spatial and temporal distribution of inorganic nutrients and factors controlling their distributions in Gwangyang Bay. Ocean Polar Res. 2005, 27, 359-379.

22. Kim, S.-J.; Lee, H.-I.; Kim, D.-C.; Shin, I.-C. Changes in sedimentary process by POSCO's dredging and reclaming in the Kwangyang Bay. J. Korean Soc. Mar. Environ. Eng. 2000, 35, 61-65.

23. Baek, S.-H.; Kim, D.; Son, M.; Yun, S.-M.; Kim, Y.-O. Seasonal distribution of phytoplankton assemblages and nutrient-enriched bioassays as indicators of nutrient limitation of phytoplankton growth in Gwangyang Bay, Korea. Estuar. Coast. Shelf Sci. 2015, 163, 265-278. [CrossRef]

24. Kang, Y.; Kang, Y.-H.; Kim, J.-K.; Kang, H.Y.; Kang, C.-K. Year-to-year variation in phytoplankton biomass in an anthropogenically polluted and complex estuary: A novel paradigm for river discharge influence. Mar. Pollut. Bull. 2020, 161, 111756. [CrossRef] [PubMed]

25. Lee, S. Study on the Zooplankton Community of Gwangyang Bay, in Spring 2006. Master's Thesis, Hanyang University, Seoul, Korea, 2009.

26. Lee, S. Long Term Variation of Zooplankton Community in the Northern Channel of Gwangyang Bay. Master's Thesis, Chonnam National University, Yeosu, Korea, 2012.

27. Lee, E.H.; Seo, M.H.; Yoon, Y.-H.; Choi, S.-D.; Soh, H.Y. Environmental factors affecting zooplankton community in Gwangyang Bay. Korean J. Environ. Biol. 2017, 35, 631-639. [CrossRef]

28. Lee, M.; Park, B.S.; Baek, S.H. Tidal influences on biotic and abiotic factors in the Seomjin River Estuary and Gwangyang Bay, Korea. Estuaries Coasts 2018, 41, 1977-1993. [CrossRef]

29. Soh, H.; Suh, H.-L. Seasonal fluctuation of the abundance of the planktonic copepods in Kwangyang Bay. Korean J. Environ. Biol. 1993, 11, 26-34.

30. Jo, H.; Kim, D.-K.; Park, K.; Kwak, I.-S. Discrimination of spatial distribution of aquatic organisms in a coastal ecosystem using eDNA. Appl. Sci. 2019, 9, 3450. [CrossRef]

31. Huh, S.H.; Kwak, S.N. Species composition and seasonal variations of fishes in eelgrass (Zostera marina) bed in Kwangyang Bay. Korean J. Ichthyol. 1997, 9, 202-220.

32. Kang, Y.; Tang, Y.Z.; Taylor, G.T.; Gobler, C.J. Discovery of a resting stage in the harmful, brown-tide-causing pelagophyte, Aureoumbra lagunensis: A mechanism potentially facilitating recurrent blooms and geographic expansion. J. Phycol. 2017, 53, 118-130. [CrossRef] [PubMed]

33. Kang, Y.; Kudela, R.M.; Gobler, C.J. Quantifying nitrogen assimilation rates of individual phytoplankton species and plankton groups during harmful algal blooms via sorting flow cytometry. Limnol. Oceanogr. Methods 2017, 15, 706-721. [CrossRef]

34. Ojala, A. Studies of Growth Rates of Some Freshwater Cryptophyte Algae; Loughborough University: Loughborough, UK, 1991.

35. Bae, S.W.; Kim, D.; Kim, Y.O.; Moon, C.H.; Baek, S.H. The influences of additional nutrients on phytoplankton growth and horizontal phytoplankton community distribution during the autumn season in Gwangyang Bay, Korea. Korean J. Environ. Biol. 2014, 32, 35-48. [CrossRef] 
36. Shim, J.H.; Shin, Y.K.; Lee, W.H. On the phyroplankton distribution in the Kwangyang Bay. J. Korean Soc. Oceanogr. 1984, 19, 176-186.

37. Klaveness, D. Biology and ecology of the Cryptophyceae: Status and challenges. Biol. Oceanogr. 1989, 6, $257-270$.

38. Šupraha, L.; Bosak, S.; Ljubešić, Z.; Mihanović, H.; Olujić, G.; Mikac, I.; Viličić, D. Cryptophyte bloom in a Mediterranean estuary: High abundance of Plagioselmis cf. prolonga in the Krka River estuary (Eastern Adriatic Sea). Sci. Mar. 2014, 78, 329-338.

39. Dortch, Q.; Whitledge, T.E. Does nitrogen or silicon limit phytoplankton production in the Mississippi River plume and nearby regions? Cont. Shelf Res. 1992, 12, 1293-1309. [CrossRef]

40. Jang, M.-C.; Jang, P.-G.; Shin, K.-S.; Park, D.-W.; Jang, M. Seasonal variation of zooplankton community in Gwangyang Bay. Korean J. Environ. Biol. 2004, 22, 11-29.

41. Tiselius, P.; Saiz, E.; Kiørboe, T. Sensory capabilities and food capture of two small copepods, Paracalanus parvus and Pseudocalanus sp. Limnol. Oceanogr. 2013, 58, 1657-1666. [CrossRef]

42. Chen, M.; Kim, D.; Liu, H.; Kang, C.-K. Variability in copepod trophic levels and feeding selectivity based on stable isotope analysis in Gwangyang Bay of the southern coast of the Korean Peninsula. Biogeosciences 2018, 15, 2055-2073. [CrossRef]

43. Chen, B.; Landry, M.R.; Huang, B.; Liu, H. Does warming enhance the effect of microzooplankton grazing on marine phytoplankton in the ocean? Limnol. Oceanogr. 2012, 57, 519-526. [CrossRef]

44. Tester, P.A.; Turner, J.T. How long does it take copepods to make eggs? J. Exp. Mar. Biol. Ecol. 1990, 141, 169-182. [CrossRef]

45. Jones, R.H.; Flynn, K.J. Nutritional status and diet composition affect the value of diatoms as copepod prey. Science 2005, 307, 1457-1459. [CrossRef]

46. Boyd, P.W.; Rynearson, T.A.; Armstrong, E.A.; Fu, F.; Hayashi, K.; Hu, Z.; Hutchins, D.A.; Kudela, R.M.; Litchman, E.; Mulholland, M.R.; et al. Marine phytoplankton temperature versus growth responses from polar to tropical waters-Outcome of a scientific community-Wide study. PLoS ONE 2013, 8, e63091. [CrossRef]

47. Fawcett, S.E.; Lomas, M.; Casey, J.R.; Ward, B.B.; Sigman, D.M. Assimilation of upwelled nitrate by small eukaryotes in the Sargasso Sea. Nat. Geosci. 2011, 4, 717-722. [CrossRef]

48. Lomas, M.; Glibert, P. Interactions between $\mathrm{NH}_{+4}$ and $\mathrm{NO}^{-}{ }_{3}$ uptake and assimilation: Comparison of diatoms and dinoflagellates at several growth temperatures. Mar. Biol. 1999, 133, 541-551. [CrossRef]

49. Lomas, M.W.; Bonachela, J.A.; Levin, S.A.; Martiny, A.C. Impact of ocean phytoplankton diversity on phosphate uptake. Proc. Natl. Acad. Sci. USA 2014, 111, 17540-17545. [CrossRef]

50. Orchard, E.D.; Ammerman, J.W.; Lomas, M.W.; Dyhrman, S.T. Dissolved inorganic and organic phosphorus uptake in Trichodesmium and the microbial community: The importance of phosphorus ester in the Sargasso Sea. Limnol. Oceanogr. 2010, 55, 1390-1399. [CrossRef]

51. Ger, K.A.; Naus-Wiezer, S.; de Meester, L.; Lürling, M. Zooplankton grazing selectivity regulates herbivory and dominance of toxic phytoplankton over multiple prey generations. Limnol. Oceanogr. 2019, 64, 1214-1227. [CrossRef]

52. Motwani, N.H.; Gorokhova, E. Mesozooplankton grazing on picocyanobacteria in the Baltic Sea as inferred from molecular diet analysis. PLoS ONE 2013, 8, e79230. [CrossRef]

53. Sailley, S.F.; Polimene, L.; Mitra, A.; Atkinson, A.; Allen, J.I. Impact of zooplankton food selectivity on plankton dynamics and nutrient cycling. J. Plankton Res. 2015, 37, 519-529. [CrossRef] 